\title{
Tacrolimus (FK506) suppresses TNF- $\alpha$-induced CCL2 (MCP-1) and CXCL10 (IP-10) expression via the inhibition of p38 MAP kinase activation in human colonic myofibroblasts
}

\author{
TOMOKI AOMATSU ${ }^{1,2}$, HIROTSUGU IMAEDA ${ }^{1}$, KENICHIRO TAKAHASHI $^{3}$, TAKEHIDE FUJIMOTO ${ }^{3}$, \\ EIJI KASUMI ${ }^{3}$, ATSUSHI YODEN ${ }^{2}$, HIROSHI TAMAI ${ }^{2}$, YOSHIHIDE FUJIYAMA ${ }^{1}$ and AKIRA ANDOH ${ }^{3}$ \\ ${ }^{1}$ Department of Medicine, Shiga University of Medical Science, Seta Tsukinowa, Otsu 520-2192; \\ ${ }^{2}$ Department of Pediatrics, Osaka Medical Collage, Takatsuki 569-8686; ${ }^{3}$ Division of Mucosal Immunology, \\ Graduate School, Shiga University of Medical Science, Seta Tsukinowa, Otsu 520-2192, Japan
}

Received May 8, 2012; Accepted July 9, 2012

DOI: $10.3892 /$ ijmm.2012.1094

\begin{abstract}
In order to investigate the molecular mechanisms underlying the immunosuppressive effects of tacrolimus (FK506) on intestinal inflammation, we examined whether FK506 effects cytokine/chemokine secretion in human colonic myofibroblasts. Human colonic myofibroblasts were isolated from normal human colonic tissue. The mRNA and protein expression for human CCL2 and CXCL10 were analyzed by real-time PCR and ELISA, respectively. p38 MAP kinase activation was evaluated by western blotting. Tacrolimus (1 $\mu \mathrm{M})$ suppressed tumor necrosis factor (TNF)- $\alpha$-induced CCL2 and CXCL10 mRNA expression, but did not modulate TNF- $\alpha$-induced interleukin (IL)- 6 or CXCL8 mRNA expression. Dose-dependent, inhibitory effects of tacrolimus on CCL2 and CXCL10 expression were observed at the mRNA and protein levels. Significant inhibitory effects of tacrolimus were observed at concentrations as low as $0.5 \mu \mathrm{M}$ for CCL2 and $0.1 \mu \mathrm{M}$ for CXCL10, respectively. TNF- $\alpha$-induced CCL2 and CXCL10 expression depended on p38 MAP kinase activation, and tacrolimus strongly inhibited the TNF- $\alpha$-induced phosphorylation of p38 MAP kinase. Tacrolimus did not affect interferon (IFN)- $\gamma$-induced signaling transducer and activator of transcription (STAT)-1 phosphorylation, nor did it modulate CXCL10 mRNA and protein expression. In conclusion, tacrolimus suppressed CCL2 and CXCL10 expression in human colonic myofibroblasts. These inhibitory effects of tacrolimus may play key roles in the therapeutic effects of colonic inflammation in inflammatory bowel disease (IBD) patients.
\end{abstract}

Correspondence to: Professor Akira Andoh, Division of Mucosal Immunology, Graduate School, Shiga University of Medical Science, Seta Tukinowa, Otsu 520-2192, Japan

E-mail: andoh@belle.shiga-med.ac.jp

Key words: inflammatory bowel disease, chemokine, tumor necrosis factor- $\alpha$

\section{Introduction}

Inflammatory bowel diseases (IBDs), including ulcerative colitis (UC) and Crohn's disease (CD), are chronic and relapsing intestinal disorders of unknown etiology (1-5). There is currently no pharmaceutical cure for IBD, and hence treatment options aim for inducing and maintaining remission. Steroids are used to induce remission but they cannot be used to maintain remission (6). Azathioprine, 6-mercaptopurine, methotrexate and biologics such as infliximab or adalimumab are all options in treating IBD (7). Despite treatment with these agents, a significant number of patients are resistant to conventional therapies and require surgery during the course of the disease to relieve their symptoms and to treat complications $(8,9)$. Regarding an alternative form of treatment, there is an increasing number of reports demonstrating the clinical efficacy of tacrolimus for steroid-dependent or steroid-refractory populations of IBD patients (8-14).

Tacrolimus (FK506) is a macrolide immunosuppressive agent isolated from Streptomyces tsukubaensis, and was first used as an immunosuppressant in transplant patients $(9,15-17)$. This immunomodulatory action of tacrolimus is based on its ability to disrupt T-cell activation and cytokine expression by binding to an intracellular protein called FK binding protein (FKBP). The complex of tacrolimus plus FKBP prevents the activation of calcineurin, resulting in an inhibition of transcription factor NFAT, which plays an important role in the transcriptional activation of genes for interleukin (IL)-2 and interferon (IFN)- $\gamma$. IL-2 is a potent growth factor for T cells, and IFN- $\gamma$ is a strong inducer of Th1 response $(18,19)$. Thus, the major immunosuppressive effects of tacrolimus are considered to be mediated by a suppression of T-cell responses via an inhibition of IL-2 and IFN- $\gamma$ secretion. However, whether tacrolimus has immunoregulatory effects on other cell types, including mesenchymal cells, remains unclear.

Chemokines and their receptors play a dominant role in orchestrating the activity of monocytes/macrophages and T cells in IBD (5), and, in particular, there is evidence that CCL2 [monocyte chemoattractant protein-1 (MCP-1)] and CXCL10 [interferon- $\gamma$-inducible protein-10 (IP-10)] are involved in 
human CD (20-23). CCL2 signaling through CCR2 is a key factor in the recruitment and activation of monocytes/macrophages, as well as in the recruitment of $\mathrm{T}$ cells to mucosal lesions (24-26). CXCL10 is a ligand for the CXCR3 receptor, the activation of which results in the recruitment of $\mathrm{T}$ cells and the perpetuation of mucosal inflammation (27).

In the present study, in order to investigate a novel aspect of the molecular mechanisms underlying the immunosuppressive effects of tacrolimus on intestinal inflammation, we examined whether this agent had an impact on cytokine/chemokine secretion in human colonic myofibroblasts. TNF- $\alpha$ plays a pivotal role in the pathogenesis of IBD $(5,28,29)$, and is widely-accepted as the major target molecule of monoclonal antibody therapy for IBD (30). Therefore, we focused on the effects of tacrolimus on TNF- $\alpha$-stimulated cytokine/chemokine [IL-6, CXCL8 (IL-8), CCL2 (MCP-1) and CXCL10 (IP-10)] expression in these cells. To our knowledge, this is the first report describing the immunosuppressive effects of tacrolimus on non-immune cells through an inhibition of p38 MAP kinase activation.

\section{Materials and methods}

Reagents and antibodies. Recombinant human TNF- $\alpha$ and IFN- $\gamma$ were purchased from R\&D Systems (Minneapolis, MN, USA). Inhibitors of p42/44 MAP kinases (PD98059), and an inhibitor of p38 MAP kinases (SB203580) were purchased from Cell Signaling Technology, Inc., (Beverly, MA, USA). A PI3K inhibitor (LY294002) was purchased from CalbiochemMerck Co. (Darmstadt, Germany). All other reagents were purchased from Sigma Chemical Co. (St. Louis, MO, USA). Goat anti-p38 MAP kinase and anti-NF- $\mathrm{BB}$ (p65) antibodies were purchased from Cell Signaling Technology, Inc. Tacrolimus was purchased from Astellas Pharma, Inc. (Tokyo, Japan).

Culture of human colonic myofibroblasts. Primary human colonic myofibroblasts were isolated and cultured according to the method reported by Mahida et al (31). The cellular characteristics and culture conditions are also described in our previous report (32).

Quantification of human CCL2 and CXCL10. Antigenic CCL2 and CXCL10 in all samples were quantified by sandwich enzyme-linked immunosorbent assay (ELISA) kits purchased from R\&D Systems.

Real-time PCR. The expression of mRNA in the samples was assessed by real-time PCR analyses. Real-time PCR was performed using a LightCycler 2.0 system (Roche Applied Science, Tokyo, Japan). The PCR was performed using a SYBR-Green PCR Master Mix (Applied Biosystems, Foster City, CA, USA). The oligonucleotide primers used in this study are described in our previous reports (33-35). The data were normalized vs. $\beta$-actin for human CCL2 and CXCL10.

Western blot analyses. The stimulated cells were lysed in an SDS sample buffer containing orthovanadate. Western blot analyses were then performed according to the method previously described (34). The detection was performed using the enhanced chemiluminescence western blotting system.
Immunohistochemical analysis for p38 MAPK activation. The cells were cultured in an 8-well chamber slide system (Nalgene, Naperville, IL, USA) for predetermined times. The cells were then fixed in cold methanol and acetone, and air dried. The samples were incubated with an anti-p38 MAPK antibody and subsequently incubated with a fluorescein isothiocyanate (FITC)-labeled goat anti-rabbit IgG (Santa Cruz Biotechnology, Inc., Santa Cruz, CA, USA).

Statistical analysis. The statistical significance of the differences was determined by the Mann-Whitney U test (Statview version 4.5). Differences resulting in P-values <0.05 were considered to be statistically significant.

\section{Results}

Effects of tacrolimus on TNF- $\alpha$-induced cytokine/chemokine mRNA expression. Human colonic myofibroblasts were stimulated for $24 \mathrm{~h}$ with TNF- $\alpha(30 \mathrm{ng} / \mathrm{ml})$ in the presence or absence of tacrolimus $(1 \mu \mathrm{M})$, and then the mRNA expression for CCL2, CXCL10, IL-6 and CXCL8 (IL-8) was analyzed by real-time PCR. TNF- $\alpha$ significantly upregulated the mRNA expression for CCL2 and CXCL10, and the presence of tacrolimus $(1 \mu \mathrm{M})$ markedly suppressed the TNF- $\alpha$-induced CCL2 and CXCL10 mRNA expression (Fig. 1A and B). TNF- $\alpha$ also induced a significant increase in mRNA expression for IL-6 and CXCL8, but tacrolimus failed to suppress TNF- $\alpha$-induced IL-6 and CXCL8 mRNA expression (Fig. 1C and D). These findings indicate that tacrolimus selectively inhibits TNF- $\alpha$ induced CCL2 and CXCL10 expression in human colonic myofibroblasts.

Dose-dependent inhibitory effects of tacrolimus. Human colonic myofibroblasts were stimulated for $24 \mathrm{~h}$ with TNF- $\alpha$ $(30 \mathrm{ng} / \mathrm{ml})$ in the presence of increasing concentrations of tacrolimus, and the mRNA expression for CCL2 and CXCL10 was analyzed by real-time PCR. Tacrolimus dose-dependently suppressed TNF- $\alpha$-induced CCL 2 and CXCL10 mRNA expression (Fig. 2A and B). Significant inhibitory effects for tacrolimus were observed at concentrations as low as $0.5 \mu \mathrm{M}$ for CCL2 and $0.1 \mu \mathrm{M}$ for CXCL10, respectively.

The inhibitory effects of tacrolimus were also investigated at the protein level. The cells were stimulated for $24 \mathrm{~h}$ with TNF- $\alpha(30 \mathrm{ng} / \mathrm{ml})$ in the presence of increasing concentrations of tacrolimus, and the CCL2 and CXCL10 secretion into the supernatants was analyzed by ELISA. Tacrolimus dosedependently suppressed TNF- $\alpha$-induced CCL2 and CXCL10 protein secretion (Fig. 2C and D).

Tacrolimus selectively inhibits p38 MAP kinase activation. Previous studies have shown that the activation of $N F-\kappa B$ and p38 MAP kinase plays an important role in TNF- $\alpha$-induced CXCL10 expression in various cell types (36-39). In addition, we have previously demonstrated that the activation of $\mathrm{NF}-\kappa \mathrm{B}$ and p38 MAP kinase is involved in TNF- $\alpha$-induced IL-6, CXCL8 and CCL2 expression in human colonic myofibroblasts (40). Based on this background information, we investigated how tacrolimus affects the TNF- $\alpha$-induced phosphorylation of NF- $\kappa \mathrm{B}$ and p38 MAP kinase in human colonic myofibroblasts. Tacrolimus had no effect on NF- $\kappa \mathrm{B}$ p65 phos- 

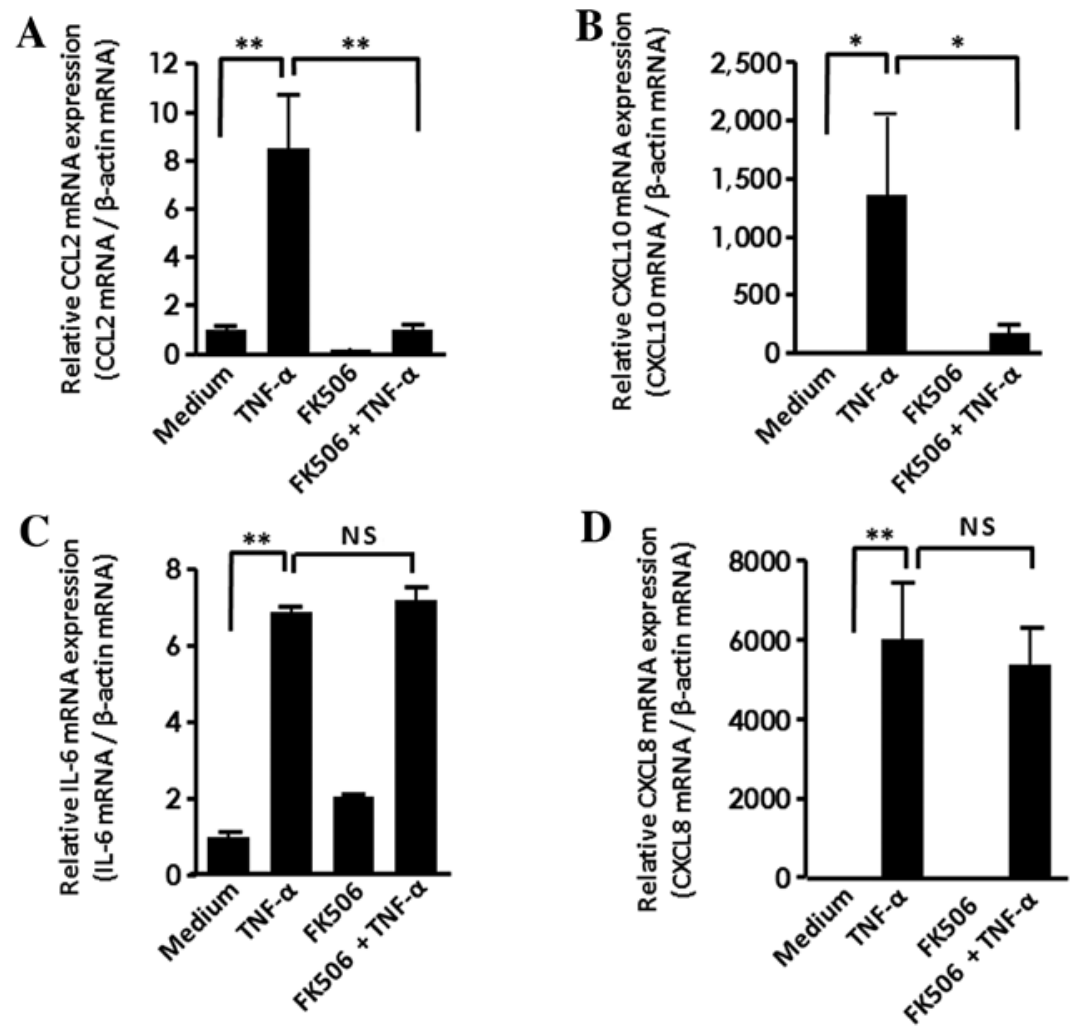

Figure 1. Effects of tacrolimus (FK506) on the TNF- $\alpha$-induced mRNA expression of CCL2 (MCP-1), CXCL10 (IP-10), IL-6 and CXCL8 (IL-8) in human colonic myofibroblasts. The cells were stimulated for $24 \mathrm{~h}$ with TNF- $\alpha(30 \mathrm{ng} / \mathrm{ml})$ in the presence or absence of tacrolimus $(1 \mu \mathrm{M})$, and then the mRNA expression for CCL2, CXCL10, IL-6 and CXCL8 (IL-8) was analyzed by real-time PCR. The data were normalized vs. $\beta$-actin for all subjects. All values are expressed as means $\pm \mathrm{SD}(\mathrm{n}=4) .{ }^{*} \mathrm{P}<0.05,{ }^{* *} \mathrm{P}<0.01$. NS, not significant.
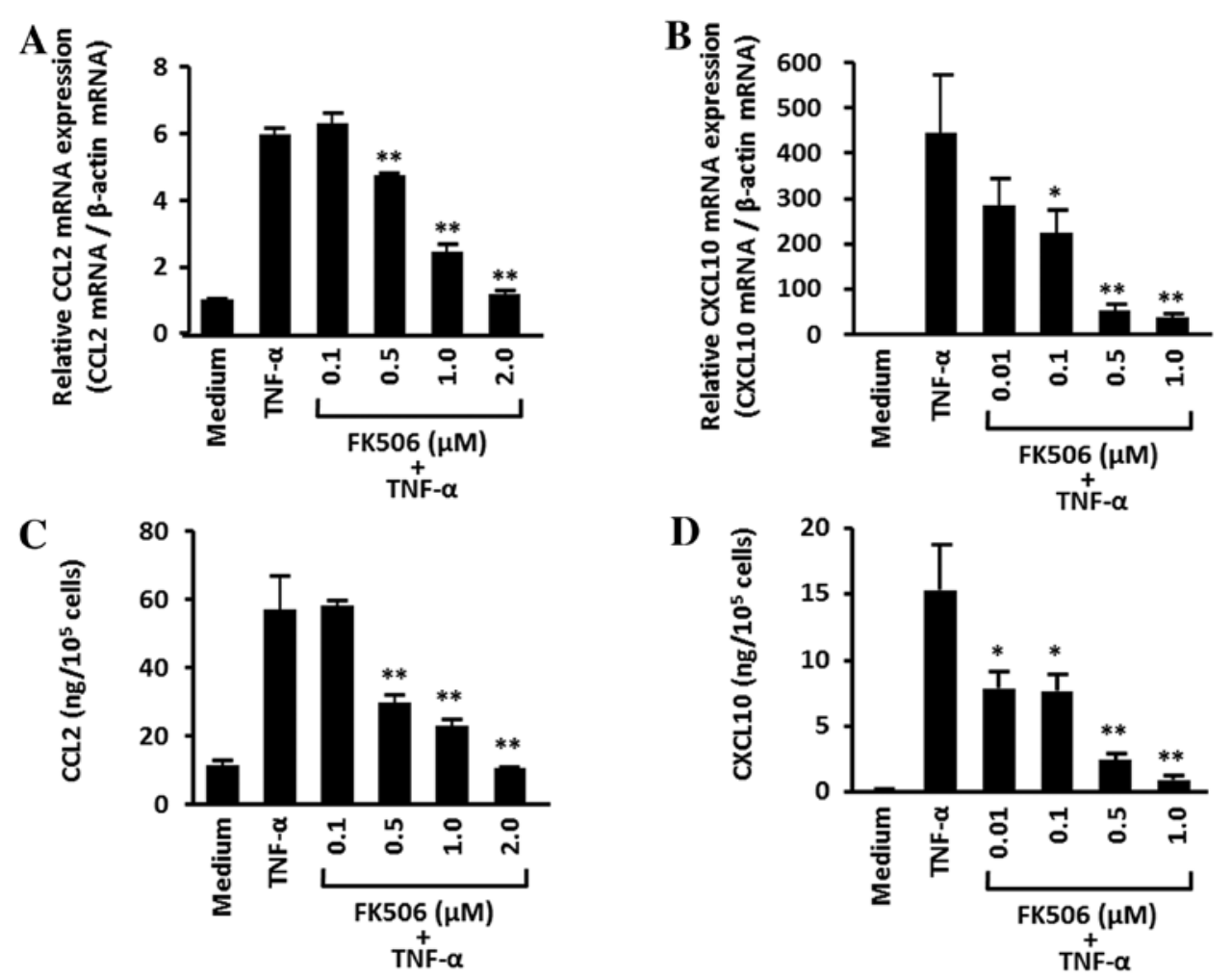

Figure 2. Effects of tacrolimus (FK506) on the TNF- $\alpha$-induced mRNA and protein expression of CCL2 (MCP-1) and CXCL10 (IP-10). (A and B) Human colonic myofibroblasts were stimulated for $24 \mathrm{~h}$ with TNF- $\alpha(30 \mathrm{ng} / \mathrm{ml})$ in the presence of increasing concentrations of tacrolimus (FK506), and the mRNA expression for CCL2 and CXCL10 was analyzed by real-time PCR. (C and D) Similarly, the cells were stimulated for $24 \mathrm{~h}$, and the CCL2 and CXCL10 protein secretion was evaluated by ELISA. The data for the mRNA expression were normalized vs. $\beta$-actin in all subjects. All values are expressed as means \pm SD $(\mathrm{n}=4) .{ }^{*} \mathrm{P}<0.05,{ }^{* *} \mathrm{P}<0.01$ vs. TNF- $\alpha$ stimulation. 


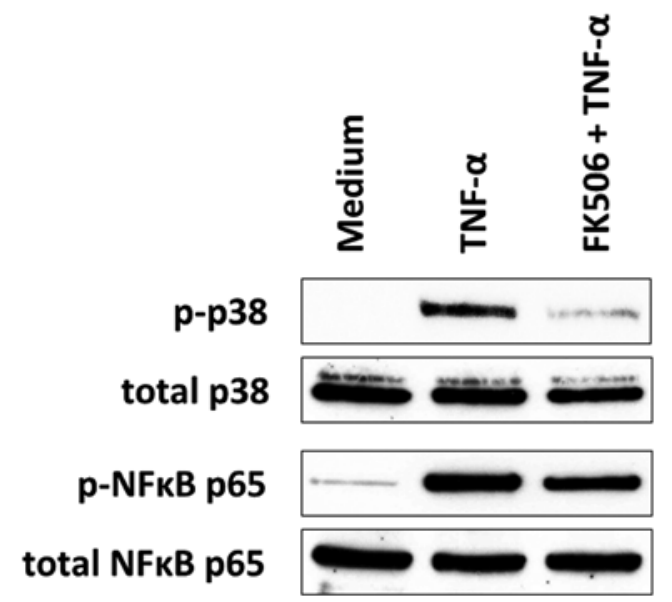

Figure 3. Effects of tacrolimus (FK506) on the TNF- $\alpha$-induced activation of p38 MAP kinase and NF- $\mathrm{KB}$ transcription factor. Colonic myofibroblasts were stimulated for $30 \mathrm{~min}$ with TNF- $\alpha(30 \mathrm{ng} / \mathrm{ml})$ in the presence or absence of tacrolimus (FK506) $(1 \mu \mathrm{M})$. The activation of the p38 MAP kinase and NF- $\mathrm{KB}$ was evaluated by western blotting. Antibodies against the phosphorylated (p)- and total-p38 MAP kinase and NF-кB p65 subunit were used.

phorylation, suggesting that the inhibition of NF- $\mathrm{KB}$ activation is not involved in the inhibitory actions of tacrolimus (Fig. 3). This is supported by the finding that tacrolimus did not affect the TNF- $\alpha$-induced expression of IL-6 and CXCL8, which induction is closely associated with NF- $\mathrm{KB}$ activation.

By contrast, tacrolimus strongly inhibited the TNF- $\alpha$ induced phosphorylation of p38 MAP kinase in these cells (Fig. 3). Furthermore, immunohistochemical staining for p38 MAP kinase showed that TNF- $\alpha$ rapidly induced the accumulation of p38 MAP kinase into the nucleus, and that tacrolimus completely blocked this response (Fig. 4). To confirm the role of p38 MAP kinase in our system, the effects of various MAP kinase inhibitors were studied. SB203580 (a specific inhibitor for p38 MAP kinase) exhibited significant inhibition against TNF- $\alpha$-induced CCL2 and CXCL10 expression, but p42/44 MAP kinase inhibitor (PD98059) and a PI3 kinase inhibitor (LY294002) had no effect (Fig. 5).

Tacrolimus does not affect IFN- $\gamma$-induced CXCL10 expression. We previously demonstrated that IFN- $\gamma$ induced CXCL10 expression via the activation of signaling transducer and activator of transcription-1 (STAT1) in human colonic myofibroblasts (35). Therefore, we tested the effects of tacrolimus on this response. Tacrolimus did not affect IFN- $\gamma$-induced STAT1 phosphorylation, nor did it modulate CXCL10 mRNA or protein expression (Fig. 6). These observations suggest that the inhibitory effects of tacrolimus on CXCL10 expression are specific for $\mathrm{TNF}-\alpha$-induced responses.

\section{Discussion}

In this study, we investigated whether tacrolimus exerted inhibitory effects on human colonic myofibroblasts, and found that tacrolimus directly inhibited TNF- $\alpha$-stimulated chemokine (CCL2 and CXCL10) production in these cells. Colonic myofibroblasts are significantly involved in the regulation of a number of epithelial cell functions, such as proliferation, differentiation, and extracellular matrix (ECM) metabolism affecting the growth of the basement membrane (40). These findings indicate that tacrolimus modulates the immunological functions of colonic myofibroblasts and contributes to the therapeutic action of tacrolimus in IBD patients.

In human colonic myofibroblasts, tacrolimus did not modulate TNF- $\alpha$-induced IL- 6 and CXCL8 expression, but selectively inhibited TNF- $\alpha$-induced CCL2 and CXCL10

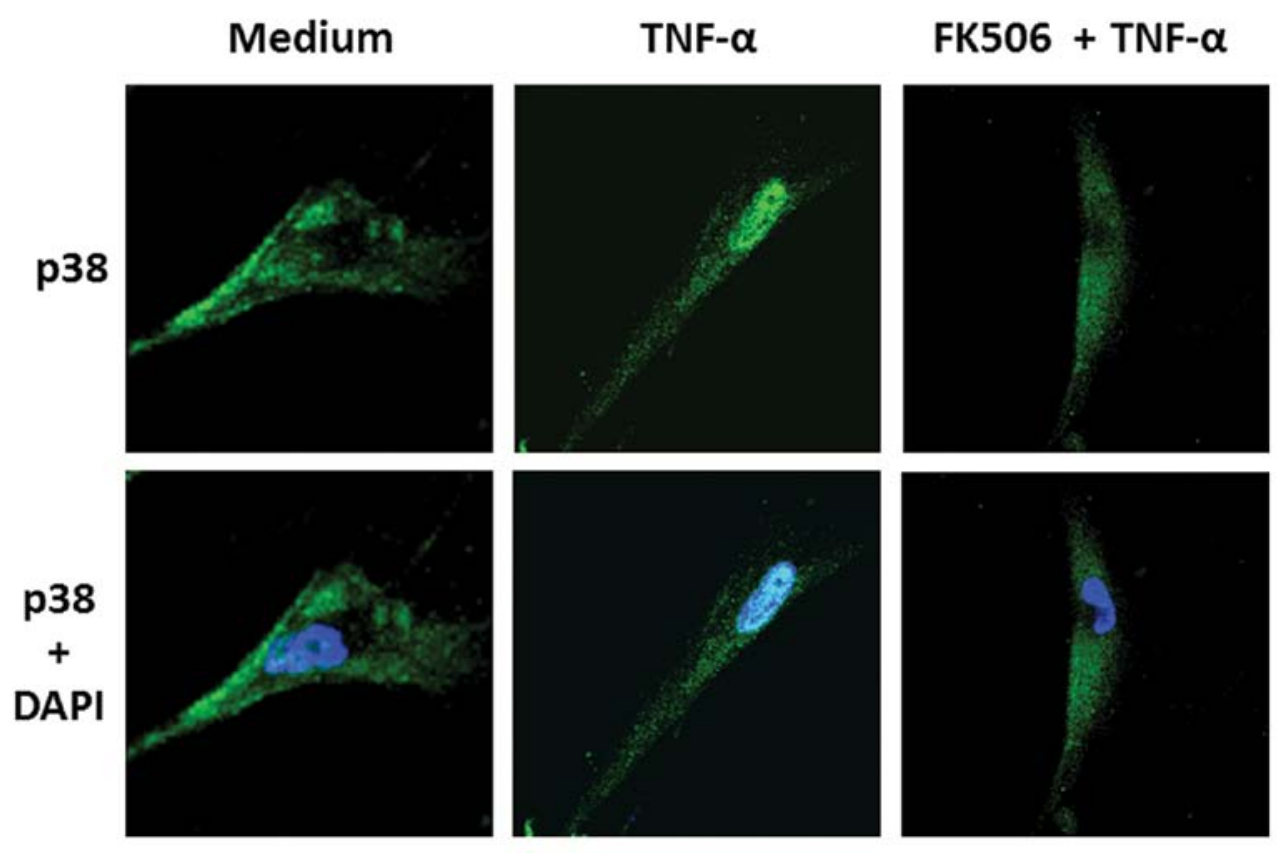

Figure 4. Immunohistochemical detection of p38 MAP kinase. The cells were cultured for $30 \mathrm{~min}$ with TNF- $\alpha$ ( $30 \mathrm{ng} / \mathrm{ml}$ ) in the presence or absence of tacrolimus (FK506) $(1 \mu \mathrm{M})$, and were then fixed with methanol and acetone. Next, the cells were incubated with an anti-p38 antibody and an FITC-labeled second antibody. The nuclei were stained with DAPI (4',6-diamidino-2-phenylindole). 

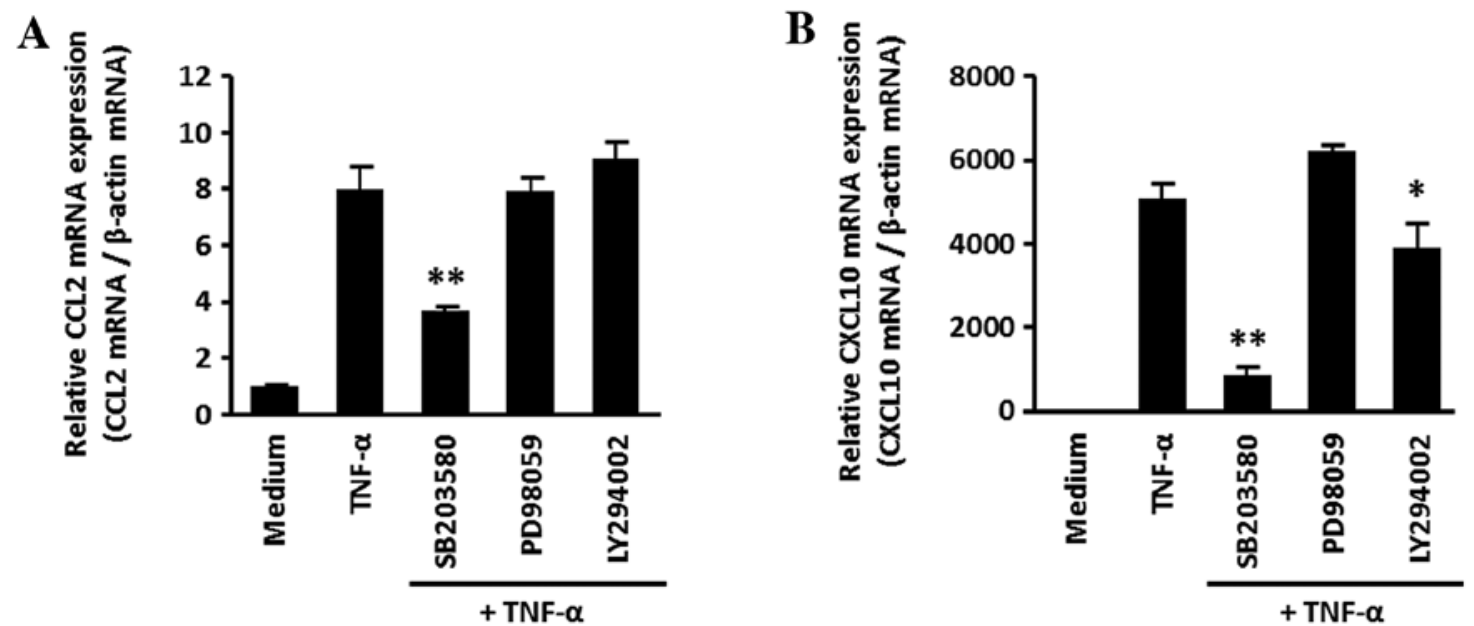

Figure 5. Effects of MAPK inhibitors and a PI3K inhibitor on TNF- $\alpha$-induced CCL2 (MCP-1) and CXCL10 (IP-10) mRNA expression. The cells were stimulated with TNF- $\alpha(30 \mathrm{ng} / \mathrm{ml})$ in the presence or absence of a p38 inhibitor [SB203580 $(15 \mu \mathrm{M})$ ], a MEK inhibitor [PD98059 (15 $\mu \mathrm{M})$ ], and a PI3K inhibitor [LY294002 $(15 \mu \mathrm{M})]$ for $24 \mathrm{~h}$, and then the CCL2 and CXCL10 mRNA expression was determined by real-time PCR. The data were normalized vs. $\beta$-actin. All values are expressed as means $\pm \mathrm{SD}(\mathrm{n}=4) .{ }^{* *} \mathrm{P}<0.01$ and ${ }^{*} \mathrm{P}<0.05$ vs. TNF- $\alpha$ stimulation.
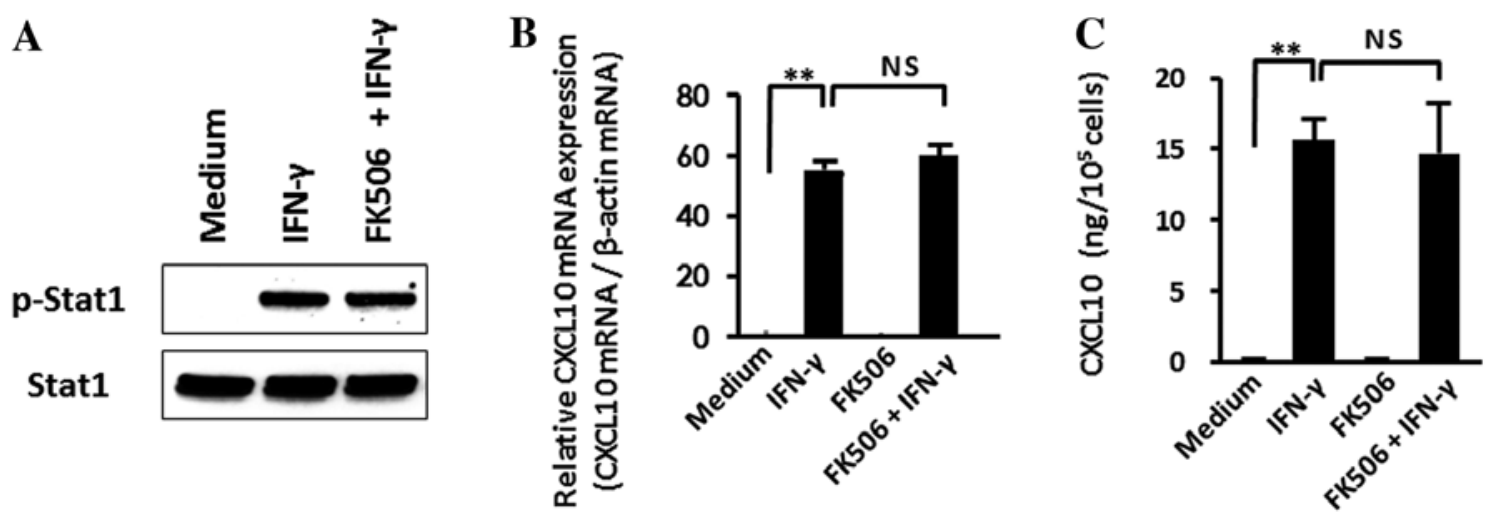

Figure 6. Effects of tacrolimus (FK506) on IFN- $\gamma$-induced STAT1 activation and CXCL10 expression. (A) Colonic myofibroblasts were stimulated for 30 min with IFN- $\gamma(30 \mathrm{ng} / \mathrm{ml})$ in the presence or absence of tacrolimus (FK506) $(1 \mu \mathrm{M})$. The activation of STAT1 was evaluated by western blotting. Antibodies against phosphorylated (p)- and total-STAT1 were used. (B) The cells were stimulated for $24 \mathrm{~h}$ with IFN- $\gamma(30 \mathrm{ng} / \mathrm{ml})$ in the presence or absence of tacrolimus (FK506) $(1 \mu \mathrm{M})$, and the CXCL10 mRNA expression was analyzed by real-time PCR. (C) The cells were stimulated for $24 \mathrm{~h} \mathrm{with} \mathrm{IFN-} \gamma(30 \mathrm{ng} / \mathrm{ml}) \mathrm{in}$ the presence or absence of tacrolimus (FK506) $(1 \mu \mathrm{M})$, and the CXCL10 protein secretion was evaluated by ELISA. The data from the mRNA expression were normalized vs. $\beta$-actin for all subjects. All values are expressed as means $\pm \mathrm{SD}(\mathrm{n}=4)$. ${ }^{* *} \mathrm{P}<0.01$. NS, not significant.

production. Previous studies have demonstrated that the activation of transcription factor $\mathrm{NF}-\kappa \mathrm{B}$ is critical for the induction of all these cytokine/chemokines (IL-6, CXCL8, CCL2 and CXCL10). However, the selective inhibitory effects of tacrolimus on CCL2 and CXCL10 suggest that the modulation of $\mathrm{NF}-\kappa \mathrm{B}$ activation is not associated with the inhibitory action of tacrolimus. This hypothesis is supported by the finding that tacrolimus did not affect the TNF- $\alpha$-induced phosphorylation of the NF- $\kappa$ B p65 subunit. Thus, the inhibitory actions of tacrolimus are possibly mediated by molecular mechanisms independent of $\mathrm{NF}-\kappa \mathrm{B}$ activation.

In human colonic myofibroblasts, tacrolimus markedly inhibited TNF- $\alpha$-induced phosphorylation and translocation of p38 MAP kinase into the nucleus. The role of p38 MAP kinase in the induction of CCL2 and CXCL10 has previously been reported (36-39), and the p38 MAP kinase inhibitor SB203580 significantly blocked TNF- $\alpha$-induced CCL2 and CXCL10 expression in human colonic myofibroblasts. These observations suggest that the inhibitory actions of tacrolimus on CCL2 and CXCL10 expression were mainly associated with an inhibition of p38 MAP kinase activation.

Several studies describe the role of CCL2/CCR2 and CXCL10/CXCR3 in the pathophysiology of IBD (41-43). Immunohistochemical staining of gut biopsy samples from $\mathrm{CD}$ patients revealed infiltrating $\mathrm{CD}^{+} \mathrm{T}$ cells and monocytes/ macrophages that are uniformly positive for CCR2 (21). Furthermore, the disease phenotypes of $\mathrm{CD}$ have been linked to polymorphisms in the CCL2 and CCR2 genes $(44,45)$. On the other hand, CXCL10 specifically activates the CXCR3 receptor, which is predominantly expressed on activated $\mathrm{T}$ and B cells, natural killer cells, dendritic and macrophage cells (46). Manousou et al (43) demonstrated an upregulation of CCR3 and its ligands in the inflamed mucosa of IBD patients. CXCL10/CXCR3 is strongly expressed in IL-10 KO mice, a model of human IBD, and the neutralization of IP-10 attenuated the colitis in this model (47). Thus, CCL2/CCR2- and CXCL10/CXCR3-mediated immune responses are regarded as the key responses in the pathogenesis of IBD, and the inhibi- 
tory actions of tacrolimus on CCL2 and CXCL10 production from colonic myofibroblasts may be involved in the clinical immunosuppressive effects of tacrolimus.

Tacrolimus is clinically used for prophylaxis against organ rejection, autoimmune diseases and IBD. It is generally accepted that the therapeutic effects of tacrolimus are a result of its inhibitory actions on T-cell functions, but there is little information concerning the inhibitory effects of tacrolimus on non-immune cells such as colonic myofibroblasts. As an example of the inhibitory actions of tacrolimus on non-T-cell populations, Yoshino et al (48) recently reported the immunosuppressive effects of tacrolimus on macrophages. They demonstrated that the proinflammatory cytokine production from tacrolimus-treated macrophages was significantly lower than that from untreated cells. Tacrolimus suppressed the LPS-induced activation of both NF- $\kappa \mathrm{B}$ and MAPK in macrophages, and induced the apoptosis of macrophages via the activation of caspases- 3 and -9 . Combined with the observations of the present study, tacrolimus may exert its immunosuppressive properties via inhibitory actions on non- $\mathrm{T}$ cells, such as macrophages and colonic myofibroblasts, as well as T cells.

In conclusion, our results confirm the potential immunosuppressive effects of tacrolimus on human colonic myofibroblasts. These inhibitory effects of tacrolimus on colonic myofibroblasts may play a significant role in the treatment of colonic inflammation in patients with IBD.

\section{References}

1. Podolsky DK: Inflammatory bowel disease. N Engl J Med 347: 417-429, 2002

2. Mizoguchi A and Mizoguchi E: Inflammatory bowel disease, past, present and future: lessons from animal models. J Gastroenterol 43: 1-17, 2008

3. Sartor RB: Mechanisms of disease: pathogenesis of Crohn's disease and ulcerative colitis. Nat Clin Pract Gastroenterol Hepatol 3: 390-407, 2006.

4. Kobori A, Yagi Y, Imaeda H, et al: Interleukin-33 expression is specifically enhanced in inflamed mucosa of ulcerative colitis J Gastroenterol 45: 999-1007, 2010.

5. Mayer L: Evolving paradigms in the pathogenesis of IBD. J Gastroenterol 45: 9-16, 2010.

6. Faubion WA Jr, Loftus EV Jr, Harmsen WS, Zinsmeister AR and Sandborn WJ: The natural history of corticosteroid therapy for inflammatory bowel disease: a population-based study. Gastroenterology 121: 255-260, 2001.

7. Taylor KM and Irving PM: Optimization of conventional therapy in patients with IBD. Nat Rev Gastroenterol Hepatol 8: 646-656, 2011.

8. McSharry K, Dalzell AM, Leiper K and El-Matary W: Systematic review: the role of tacrolimus in the management of Crohn's disease. Aliment Pharmacol Ther 34: 1282-1294, 2011.

9. Naganuma M, Fujii T and Watanabe M: The use of traditional and newer calcineurin inhibitors in inflammatory bowel disease. J Gastroenterol 46: 129-137, 2011.

10. Benson A, Barrett T, Sparberg M and Buchman AL: Efficacy and safety of tacrolimus in refractory ulcerative colitis and Crohn's disease: a single-center experience. Inflamm Bowel Dis 14: 7-12, 2008.

11. Ogata $\mathrm{H}$, Matsui $\mathrm{T}$, Nakamura $\mathrm{M}$, et al: A randomised dose finding study of oral tacrolimus (FK506) therapy in refractory ulcerative colitis. Gut 55: 1255-1262, 2006.

12. Ogata H, Kato J, Hirai F, et al: Double-blind, placebo-controlled trial of oral tacrolimus (FK506) in the management of hospitalized patients with steroid-refractory ulcerative colitis. Inflamm Bowel Dis 18: 803-808, 2012.

13. Yamamoto S, Nakase H, Matsuura M, Masuda S, Inui K and Chiba T: Tacrolimus therapy as an alternative to thiopurines for maintaining remission in patients with refractory ulcerative colitis. J Clin Gastroenterol 45: 526-530, 2011.
14. Yamamoto S, Nakase H, Mikami S, et al: Long-term effect of tacrolimus therapy in patients with refractory ulcerative colitis. Aliment Pharmacol Ther 28: 589-597, 2008.

15. Busuttil RW and Lake JR: Role of tacrolimus in the evolution of liver transplantation. Transplantation 77: S44-S51, 2004.

16. Vincenti F: A decade of progress in kidney transplantation. Transplantation 77: S52-S61, 2004.

17. Rusnak F and Mertz P: Calcineurin: form and function. Physiological Rev 80: 1483-1521, 2000.

18. Liao W, Lin JX and Leonard WJ: IL-2 family cytokines: new insights into the complex roles of IL-2 as a broad regulator of T helper cell differentiation. Curr Opin Immunol 23: 598-604, 2011.

19. Lazarevic V and Glimcher LH: T-bet in disease. Nat Immunol 12: 597-606, 2011.

20. Singh UP, Venkataraman C, Singh R and Lillard JW Jr: CXCR3 axis: role in inflammatory bowel disease and its therapeutic implication. Endocr Metab Immune Disord Drug Targets 7: 111-123, 2007.

21. Connor SJ, Paraskevopoulos N, Newman R, et al: CCR2 expressing $\mathrm{CD}^{+} \mathrm{T}$ lymphocytes are preferentially recruited to the ileum in Crohn's disease. Gut 53: 1287-1294, 2004.

22. Grip $\mathrm{O}$ and Janciauskiene S: Atorvastatin reduces plasma levels of chemokine (CXCL10) in patients with Crohn's disease. PLoS One 4: e5263, 2009.

23. Banks C, Bateman A, Payne R, Johnson P and Sheron N: Chemokine expression in IBD. Mucosal chemokine expression is unselectively increased in both ulcerative colitis and Crohn's disease. J Pathol 199: 28-35, 2003.

24. Zhang HH, Song K, Rabin RL, et al: CCR2 identifies a stable population of human effector memory $\mathrm{CD} 4^{+} \mathrm{T}$ cells equipped for rapid recall response. J Immunol 185: 6646-6663, 2010.

25. Charo IF and Peters W: Chemokine receptor 2 (CCR2) in atherosclerosis, infectious diseases, and regulation of T-cell polarization. Microcirculation 10: 259-264, 2003.

26. Kim YG, Kamada N, Shaw MH, et al: The Nod2 sensor promotes intestinal pathogen eradication via the chemokine CCL2dependent recruitment of inflammatory monocytes. Immunity 34: 769-780, 2011.

27. Liu M, Guo S, Hibbert JM, et al: CXCL10/IP-10 in infectious diseases pathogenesis and potential therapeutic implications. Cytokine Growth Factor Rev 22: 121-130, 2011.

28. Danese S, Colombel JF, Reinisch W and Rutgeerts PJ: Review article: infliximab for Crohn's disease treatment - shifting therapeutic strategies after 10 years of clinical experience. Aliment Pharmacol Ther 33: 857-869, 2011.

29. Hanauer SB, Kornbluth AA, Messick J, Rubin DT, Sandborn WJ and Sands BE: Clinical scenarios in IBD: optimizing the use of conventional and biologic agents. Inflamm Bowel Dis 16: S1-S11, 2010.

30. Allez M, Vermeire S, Mozziconacci N, et al: The efficacy and safety of a third anti-TNF monoclonal antibody in Crohn's disease after failure of two other anti-TNF antibodies. Aliment Pharmacol Ther 31: 92-101, 2010.

31. Mahida YR, Beltinger J, Makh S, et al: Adult human colonic subepithelial myofibroblasts express extracellular matrix proteins and cyclooxygenase-1 and -2. Am J Physiol 273: G1341-G1348, 1997.

32. Okuno T, Andoh A, Bamba S, et al: Interleukin-1beta and tumor necrosis factor-alpha induce chemokine and matrix metalloproteinase gene expression in human colonic subepithelial myofibroblasts. Scand J Gastroenterol 37: 317-324, 2002.

33. Andoh A, Takaya H, Saotome T, et al: Cytokine regulation of chemokine (IL-8, MCP-1, and RANTES) gene expression in human pancreatic periacinar myofibroblasts. Gastroenterology 119: 211-219, 2000.

34. Shimada M, Andoh A, Hata K, et al: IL-6 secretion by human pancreatic periacinar myofibroblasts in response to inflammatory mediators. J Immunol 168: 861-868, 2002.

35. Inatomi $\mathrm{O}$, Andoh $\mathrm{A}$, Kitamura $\mathrm{K}$, Yasui $\mathrm{H}$, Zhang $\mathrm{Z}$ and Fujiyama Y: Butyrate blocks interferon-gamma-inducible protein-10 release in human intestinal subepithelial myofibroblasts. J Gastroenterol 40: 483-489, 2005.

36. Qi XF, Kim DH, Yoon YS, et al: Essential involvement of crosstalk between IFN-gamma and TNF-alpha in CXCL10 production in human THP-1 monocytes. J Cell Physiol 220: 690-697, 2009.

37. Wu C, Ohmori Y, Bandyopadhyay S, Sen G and Hamilton T: Interferon-stimulated response element and NF kappa B sites cooperate to regulate double-stranded RNA-induced transcription of the IP-10 gene. J Interferon Res 14: 357-363, 1994. 
38. Shultz DB, Rani MR, Fuller JD, Ransohoff RM and Stark GR: Roles of IKK-beta, IRF1, and p65 in the activation of chemokine genes by interferon-gamma. J Interferon Cytokine Res 29: 817-824, 2009.

39. Wong CK, Wang CB, Ip WK, Tian YP and Lam CW: Role of p38 MAPK and NF- $\kappa$ B for chemokine release in coculture of human eosinophils and bronchial epithelial cells. Clin Exp Immunol 139: 90-100, 2005.

40. Hata K, Andoh A, Shimada M, et al: IL-17 stimulates inflammatory responses via NF-kappaB and MAP kinase pathways in human colonic myofibroblasts. Am J Physiol Gastrointest Liver Physiol 282: G1035-G1044, 2002.

41. Reinecker HC, Loh EY, Ringler DJ, Mehta A, Rombeau JL and MacDermott RP: Monocyte-chemoattractant protein 1 gene expression in intestinal epithelial cells and inflammatory bowel disease mucosa. Gastroenterology 108: 40-50, 1995.

42. Uguccioni M, Gionchetti P, Robbiani DF, et al: Increased expression of IP-10, IL-8, MCP-1, and MCP-3 in ulcerative colitis. Am J Pathol 155: 331-336, 1999.

43. Manousou P, Kolios G, Valatas V, et al: Increased expression of chemokine receptor CCR3 and its ligands in ulcerative colitis: the role of colonic epithelial cells in in vitro studies. Clin Exp Immunol 162: 337-347, 2010.
44. Herfarth H, Pollok-Kopp B, Goke M, Press A and Oppermann M: Polymorphism of CC chemokine receptors CCR2 and CCR5 in Crohn's disease. Immunol Lett 77: 113-117, 2001.

45. Herfarth H, Goke M, Hellerbrand C, et al: Polymorphism of monocyte chemoattractant protein 1 in Crohn's disease. Int J Colorectal Dis 18: 401-405, 2003.

46. Egan CE, Craven MD, Leng J, Mack M, Simpson KW and Denkers EY: CCR2-dependent intraepithelial lymphocytes mediate inflammatory gut pathology during Toxoplasma gondii infection. Mucosal Immunol 2: 527-535, 2009.

47. Singh UP, Singh S, Taub DD and Lillard JW Jr: Inhibition of IFN-gamma-inducible protein-10 abrogates colitis in IL-10-/mice. J Immunol 171: 1401-1406, 2003.

48. Yoshino T, Nakase H, Honzawa Y, et al: Immunosuppressive effects of tacrolimus on macrophages ameliorate experimental colitis. Inflamm Bowel Dis 16: 2022-2033, 2010. 